\title{
Chapter 23 \\ Contemporary Problems of Well-being and How We Got Here
}

\author{
John Grin
}

\section{Contents}

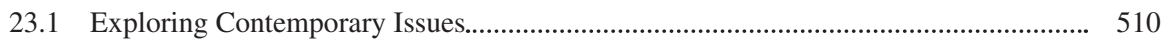

23.1.1 Material Flows.............................................................................................. 511

23.1.2 Fossil Energy Use........................................................................... 512

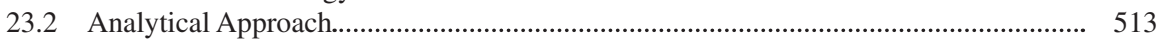

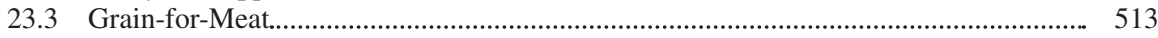

23.3.1 Breaking Circularity.................................................................................... 513

23.3.2 How the Netherlands Embedded Itself in the Grain-for-Meat Chain............... 515

23.3.3 How Nutrients Came to Leak from the Grain-for-Meat Chain......................... 516

23.3.4 Expansion of Material Flows in the Grain-for-Meat Chain.............................. 517

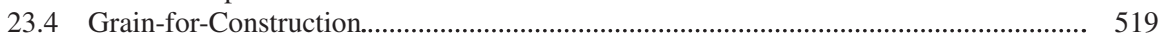

23.4.1 Contemporary Problems and Historical Trends................................................. 519

23.4.2 Volumes of Gravel: From Historically Vast Increases of Mass Flows to

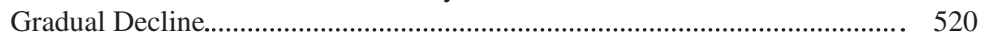

23.4.3 Increasing Construction Efforts....................................................................... 520

23.4.4 Changing Construction Practice: Concrete and More Spacious Dwellings.... 521

23.4.5 More Concrete, More Gravel............................................................................. 522

23.4.6 The End of Circularity and the Increasing Share of Import............................. 522

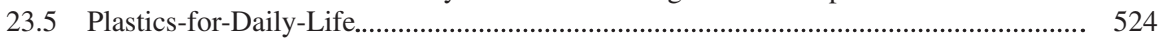

23.5.1 Exploring Contemporary Problems.................................................................... 524

23.5.2 How the Chain Became So Vast: The Plastics Revolution............................... 525

23.5.3 Understanding the Chain's Non-circularity...................................................... 528

23.5.4 Energy Consumption.................................................................................. 528

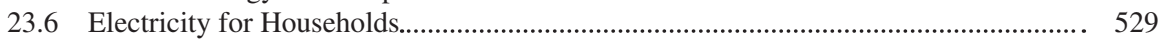

23.6.1 Exploring the Problem..................................................................................... 529

23.6.2 Households and Electricity Production............................................................... 530

23.6.3 The Evolution of Domestic Electricity Demand............................................... 531

23.6.4 The Evolution of Energy and the $\mathrm{CO}_{2}$ Intensity of Electricity Production..... 532

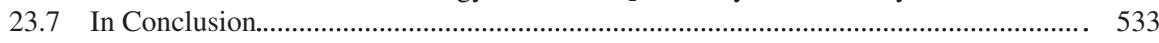

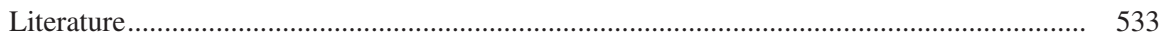

\begin{abstract}
In this chapter we analyse the historical genesis of the contemporary crisis of natural capital as groundwork for exploring possible routes for future development up to 2050. The central question is: How did currently problematic couplings between GDP growth, well-being, resource use, energy use and pollution emerge?
\end{abstract}


In this connection, we analyse three value chains (grain-for-meat; gravel-forconstruction; plastics-for-domestic-quality of life) asking the following subquestions: How did practices of production, consumption and distribution shape (1) specific value chains into non-circularity, and (2) yield a vast expansion of material flows, especially after 1960 ? What problem definitions and value orientations have guided those developments and how have they been institutionally and spatially embedded?

A fourth case is devoted to energy, in particular to electricity-for-households: How did practices of production, consumption and distribution shape the evolution of energy intensity in households? What problem definitions and value orientations guided those developments and how were they institutionally and spatially embedded?

The results of the analyses are used for reflections on future strategies to promote sustainability (see final Chap. 24).

Keywords Crisis · Natural Capital · Value Chains · Grain · Meat · Gravel · Plastics

\subsection{Exploring Contemporary Issues}

By 1960 the process of state formation and societal modernization that took off around 1850 had attained its goals: more well-being and greater democratic participation. Moreover, the underlying practices respected the available stock of natural capital. That is, until about 1960. After that, the continuous growth in GDP meant a steep increase in resource and energy consumption (Graph 22.2). This did not go unnoticed. A better-educated populace demanded more political and social say, and began to hold government and business responsible for the massive ecological problems that surfaced in the course of the 1960s. ${ }^{1}$ By 2010 social unrest posed a serious threat to Dutch democracy while in the background the country's natural capital was being consumed at alarming rates.

In this chapter we analyse the historical genesis of the contemporary crisis of natural capital as groundwork for exploring possible routes for future development up to 2050. We focus on dominant problem definitions and value orientations and the associated institutional embedding - as argued in Chap. 1. These are also salient because they co-shape future developments, the substance of Chap. 24.

For the same two reasons, we also zero in on the long-term "landscape" trends that have shaped practices (Chap. 1) especially their spatiality. Preceding chapters showed that the spatial dimension of practices deeply informs present-day

\footnotetext{
${ }^{1} \mathrm{U}$. Beck, The re-invention of politics. Rethinking Modernity in the Global Social Order (Cambridge: Polity Press, 1997).
} 
dilemmas - as emphasised in recent transition studies. ${ }^{2}$ In sum, the central question of this chapter will be:

Q: How did currently problematic couplings between GDP growth, well-being, resource I energy use and pollution emerge? What problem definitions and value orientations have guided that development and how have these been institutionally embedded?

\subsubsection{Material Flows}

While a few key resources like oil and phosphates are dwindling rapidly, increasing demand on resources in general is savaging landscapes and biodiversity at extraction locales. And though achievements like the tenfold reduction of per capita $\mathrm{SO}_{2}$ emissions, approaching 1850 levels, are hopeful, newer problems like soil acidification due to surplus manure and the pollution of the oceans by micro-plastics are still far from being solved. Such problems are rooted in two developments. The first is the way economic supply chains evolved since 1850 - especially their degrees of differentiation and specialisation. This resulted in an economy of non-circular chains of production and consumption. When, around 1960, this non-circularity intersected with a second phenomenon, a vast expansion of production and consumption, massive problems ensued (cf. Graph 22.2).

As a mercantile country traditionally poor in resources, the Netherlands has long imported crucial resources, while finished products are domestically consumed or exported. Depending on the spatial and institutional specifics of the economic supply chains involved, repercussions therefore quickly extend beyond the 'here and now' and into the 'elsewhere' and/or 'later.'

\footnotetext{
${ }^{2}$ M. Hodson, S. Marvin, Can cities shape socio-technical transitions and how would we know if they were? (Research Policy, 39: 2010), 477-485.

P. Späth, H. Rohracher, 'Energy regions: The transformative power of regional discourses on socio-technical futures' (Research Policy, 39,4: 2010), 449-458.

P. Späth, Philipp, H. Rohracher, Beyond Localism: The Spatial Scale and Scaling in Energy Transitions (Padt 2014), R. Raven, J. Schot, F. Berkhout, 2012: Space and scale in socio-technical transitions (2012), Environmental Innovation and Societal Transitions, 4, 63-78.

B. Truffer, L. Coenen, Environmental Innovation and Sustainability Transitions in Regional Studies (2012), Regional Studies, 46,1: 1-21.

A. Switzer, L. Bertolini \& J. Grin, Understanding transitions in the regional transport and landuse system: Munich 1945-2013 (2015), Town Planning Review, vol. 86 no. 6. p. 699-723., A. Switzer, L. Bertolini, J. Grin, Transitions of Mobility Systems in Urban Regions: A Heuristic Framework (2013), Environmental Policy and Planning, 15,2: 141-160.

J. Grin, N. Frantzeskaki, V. Castan Broto, L. Coenen, 'Sustainability Transitions and the City' (2015), Linking to transition studies and looking forward chapter 22 (conclusions) in: N. Frantzeskaki, V. Castan-Broto, L. Coenen (ed.s), Urban Sustainability Transitions. J. Grin, N. Frantzeskaki, V. Castan Broto, L. Coenen, Sustainability Transitions and the City (2015), Linking to transition studies and looking forward chapter 22 (conclusions) in: N. Frantzeskaki, V. Castan-Broto, L. Coenen (ed.s), Urban Sustainability Transitions.
} 
Hence the following sub-questions will inform our detailed examinations of several supply chains (grain-for-meat; gravel-for-construction; and plastics-fordomestic-quality of life):

Q1: How did practices of production, consumption and distribution shape (i) specific value chains into non-circularity, and (ii) yield a vast expansion of material flows, especially since 1960? What problem definitions and value orientations have guided those developments and how have they been institutionally and spatially embedded?

\subsubsection{Fossil Energy Use}

As Graph 22.4 indicates, air pollution due to the rapid increase in fossil energy use since the 1950s was largely solved by first generation "end of pipe" environmental policies $^{3}$ not to mention the early 1970 s transition to natural gas. But whatever the size of remaining fossil stocks, current rates of (increase of) fossil energy consumption cannot be environmentally sustained throughout the present century - certainly not in view of climate change and certainly not if developing countries seek to emulate western industrialisation since 1850 .

Depletion of fossil resources and climate change are serious problems for both 'later' (inasmuch as the consequences of depletion and the worst consequences of climate change are yet to come) and 'elsewhere' (inasmuch as the consequences of climate change will hit the global South hardest). ${ }^{4}$ That said, climate change and fossil resource depletion are also serious problems in the 'here and now.' Fossil fuel extraction has had undesirable local effects both in the Netherlands and elsewhere: its spatiality has had and will continue to have, important implications for energy security and financial flows.

Increased energy consumption is directly to blame. Graph 22.2 shows how energy consumption skyrocketed in the 1960s. This follows a similar pattern of growth in overall production and consumption and thus speaks to our first question. The coupling between material production and energy consumption obviously reflects the very nature of industrial production: using mechanical energy to augment labour productivity. And inasmuch as prior to 2010 that energy was largely fossil energy, the correlation between production and $\mathrm{CO}_{2}$ emissions also appears evident. Between 1961 and 1974 the rapid, large-scale introduction of natural gas

\footnotetext{
${ }^{3}$ J. Grin, H. van de Graaf. P. Vergragt, Een derde generatie milieubeleid: Een sociologisch perspectief en een beleidswetenschappelijk programma, (2003), Beleidswetenschap, jrg. 17, nr. 1, p. $51-71$.

${ }^{4}$ Brauch, H. Günter, Ú. Oswald Spring, J. Grin, C. Mesjasz, P. Kameri-Mbote, N. Chadha Behera, B. Chourou, H. Krummenacher, Facing Global Environmental Change: Environmental, Human, Energy, Food, Health and Water Security Concepts. (2009), Hexagon Series on Human and Environmental Security and Peace, vol. 4 (Berlin - Heidelberg - New York: Springer-Verlag).

Brauch, H. Günter, Ú. Oswald Spring, J. Grin, C. Mesjasz, P. Kameri-Mbote, N. Chadha Behera, B. Chourou, H. Krummenacher, Coping with Global Environmental Change, Disasters and Security - Threats, Challenges,
} 
mitigated $\mathrm{CO}_{2}$ emissions. At the same time, energy-intensive industries, most notably the utilities and the chemical sector, became more important in the Dutch economy. After 1974, levels of $\mathrm{CO}_{2}$ emissions were the combined effect of more efficient production (in response to the oil crises) and greater volumes of production. For most sectors in this period, increases in export were the main drivers of increased $\mathrm{CO}_{2}$ emissions. The big exception was the utilities where household consumption was responsible.

Below, therefore, we will seek answers to the following sub-questions as we analyse cases of energy use in specific chains:

Q2: How did practices of production, consumption and distribution shape the evolution of energy intensity in particular value chains? What problem definitions and value orientations guided those developments and how were they institutionally and spatially embedded?

\subsection{Analytical Approach}

We will analyse four value chains: grain-for-meat; gravel-for-construction; plasticsfor-domestic-quality of life and electricity-for-households. These cases cover much of the increase in well-being since 1850: first the satisfaction of basic needs and, especially since the 1960s, increasing convenience, comfort and fun. They also cover the spectrum of contemporary problems, partly because they exhibit different patterns of spatiality in material flows. The first three chains exemplify organic, mineral and fossil resources, respectively, selected on the basis of volume and on aboveaverage import shares for their respective categories. These three cases are used to answer Q1 above, explaining how production (and with it, emissions) increased in the three sectors. The last two cases - exemplifying the consumption and production of electricity - show how $\mathrm{CO}_{2}$ emissions evolved and will be used to answer Q2.

\subsection{Grain-for-Meat}

\subsubsection{Breaking Circularity}

Recall the two dynamics underlying contemporary sustainability problems: first, the non-circularity of economic chains and, second, their sheer volume, especially since 1960. Non-circularity in the grain-meat chain ${ }^{5}$ may be summarised by noting that by 2010 the Netherlands

\footnotetext{
${ }^{5}$ Denkgroep Duurzame Veehouderij, Toekomst voor de veehouderij. Agenda voor een herontwerp voor de sector, (2001) Advice to the Dutch Agricultural Minister.

Van Zeijts, H, M.M. van Eerdt, W.J. Willems, G.A. Rood, A.C. den Boer, D.S. Nijdam, Op weg naar een duurzame veehouderij. Ontwikkelingen tussen 2000 en 2010. (Den Haag/Bilthoven, 2010), Planbureau voor de Leefomgeving (PBL).
} 
- imported $80 \%$ of its available grain, nearly half of which was used for cattle fodder. Soy (products) alone accounted for 9 Mton (around 30\% of EU flow), mainly (75\%) from Brazil and Argentina. ${ }^{6}$

- exported $63 \%$ of its available meat, while it imported somewhat less than a third

- crop production was wedded to artificial fertilisers, which largely replaced animal manure. Hence nutrients from surplus manure end up as effluents in soil, surface waters and oceans.

As such, this chain is exemplary for the Netherlands a node of food supply chains ${ }^{7}$ (contrary to e.g. England which is more an endpoint). The classical Dutch pattern is exporting processed foodstuffs and importing raw materials like cattle fodder and vegetable oils; this fits seamlessly with what we have called "a chemical-analytical perspective on agricultural and fisheries products as raw materials for foods." (Chap. 13).

Experts associate this pattern with nutrient depletion both globally ${ }^{8}$ and in the source countries, where it also despoils landscapes and ruins soils. In the Netherlands, the dominance of animal over crop production has had similar consequences. For one thing, it entails the long-range transportation of animals and meat (Dutch pigs travel to Italy, and then Parma ham is exported everywhere, including the Netherlands) which stresses the animals, augments $\mathrm{CO}_{2}$ emissions and contributes to the spread of pandemics ${ }^{9}$ The sheer size, transnational nature and complexity of the production chain, the second core element, has only exacerbated all these problems.

How did practices of production, consumption and distribution give rise to a noncircular grain-for-meat chain; what problem perceptions and values animated these practices, and how were they institutionally and spatially structured?

\footnotetext{
${ }^{6} \mathrm{E}$. Hees, Voedsel, grondstoffen en geopolitiek. Rapportage aan het Platform Landbouw, Innovatie \& Samenleving (Culemborg 2013), 23-28.

${ }^{7}$ See ch. 13 and WRR, Naar een voedselbeleid, Den Haag/Amsterdam 2014), rapport nr. 93, 60-64.

${ }^{8}$ D. Cordell, The Story of Phosphorus:Sustainability implications of global phosphorus scarcity for food security (2010), Linköping: Linköping University Press.

M. de Ridder, S. de Jong, J. Polchar, S Lingemann, Risks and Opportunities in the Global Phosphate Rock Market (The Hague, 2013), The Hague Centre for Strategic Studies (HCSS). Rapport No $17 \mid 12$ | 12.

M. Heckenmüller, N. Daiju G. Klepper, Global Availability of Phosphorus and Its Implications for Global Food Supply: An Economic Overview (2014), Kiel Working Paper No. 1897. University of Kiel.

${ }^{9}$ Zeijts et al., Op weg naar een duurzame veehouderij (2010).
} 


\subsubsection{How the Netherlands Embedded Itself in the Grain-for- Meat Chain}

From 1850-2010 around half of the available grain in the Netherlands was used for cattle fodder. ${ }^{10}$ But increasingly, that grain has been imported. Since 1970, around $80 \%$ of the total has been imported, an increase compared to $1913(68 \%)$ and especially to $1850(21 \%)$. What lies behind this?

Specialisation was the chief culprit. This had long been the rule in the western provinces, but on the sand grounds the transition occurred between 1850 and 1913 with a shift from crop cultivation to cattle husbandry at the then still 'mixed' farms. The process (cf. Chap. 8) was triggered by the international trade liberalisation of the 1840s, the first effect of which was to substitute commercial gain for selfsufficiency as the basic normative orientation of farming on the sand grounds and around the large rivers. But it also toppled grain prices to the point of undermining mixed farming and encouraging the transformation of crop fields into grazing pastures. Given the new orientation to commercial gain and the price effects of trade liberalisation, agriculture shifted toward exporting expensive meat and importing relatively cheap grain. Industrialising England and Germany were especially enamoured of 'luxury' Dutch meat. By 1913, the Netherlands was exporting $31 \%$ of its available meat, while importing $28 \%$ - a tremendous increase compared to 1850 , when these figures were $4 \%$ and $2 \%$ respectively.

Thus crop farming increasingly focused on serving livestock farming, while the latter increasingly became a value chain in and of itself, de-coupled from crop production. Here lies the cradle of the Dutch position as a node in international food chains.

As discussed in Chap. 8, the international agricultural crisis of the 1880 s was a very rough patch for the Dutch primary sector. Still, this only accelerated the developments just sketched. The US was already decisively on the track to modernisation and, at the cost of soil depletion, was producing vast quantities of grain that could be transported cheaply to the East coast by the new railway lines. From there, steamship companies and older trade networks (the Dutch had long been global grain traders) shipped it to Europe. This seriously depressed European grain prices, further stimulating the trend that set in during the 1840 s and reinforcing the orientation to commercial gain.

The spatial and institutional embedding of these practices and their normative orientation was consolidated by ever-cheaper international transportation as well as by the shift from the commons to agricultural co-operatives with their collective bulk purchasing and selling power. Between 1850 and 1913, the total amount of available grain increased by a factor of 3.3 while the amount used for cattle farming increased by a factor of 4.5; at the same time, the share of imports more than tripled. All told, these developments yielded a shift from a circular chain centred around

\footnotetext{
${ }^{10}$ F. Lambert, Massastromen in Nederland in de jaren 1850, 1913, 1970, 2010 (Eindhoven 2016), open access researchreport, $11,17,25,35$.
} 
mixed farms working for domestic or local production to a de-localized, noncircular meat production chain.

In the wings, a newly interventionist government was also keen to maintain and expand its position by serving the national interest. After the hygienist movement had revealed the dangers of unreliable food, food quality had also become part of the normative repertoire of the food sector - with a vigilant government looking over its shoulder. Following several scandals and disputes, the government mobilised the Codex Alimentarius, developed in the late nineteenth century by the hygienists, to define standards (1902) for meat, among other things to safeguard the export market. By 1919, chronically unreliable food supplies during World War I had made a Food and Drugs Act inevitable, a move that further bolstered the position of the Netherlands as an exporter of high-quality foods, including meat.

\subsubsection{How Nutrients Came to Leak from the Grain-for-Meat Chain}

The commercialisation of farming between 1850 and 1913 also became possible thanks to the adoption of artificial fertilisers that gradually replaced the mix of animal manure, urban waste and faeces, fish and animal waste and Guano. Chili Salpeter, imported from Latin America, was a key artificial fertiliser. Other fertilisers were imported from especially Belgium and Germany, which surpassed the Netherlands both as users and as importers of artificial fertilisers well into the 1920s. (Chap. 8) By then, though, domestic Dutch production of artificial fertilisers was also rapidly increasing (see Graph 13.2). This shift was triggered by World War I, when nitrates became critical military resources, especially in those countries from which the Netherlands imported its artificial fertilisers. (Threats of) food shortages and the emergence of new political movements compelled the government to intervene. To compensate for the closing down of international trade, it forced merchants, co-operatives and importers to work together in acquisition associations to supply the superphosphate factories established in the previous decade with scarce nitrates.

These wartime changes in the institutional quadrants persisted into the post-war period. In the following years, the new networks created in the market would promote the rapid growth of the fertiliser sector; and government, once involved, continued to promote fertiliser production by supporting (semi) state enterprises like the State Mines (coal) and Hoogovens (iron and steel). These firms employed new fertiliser production methods, developed internationally during the War. The Netherlands thus swiftly developed the portion of the international market allocated to it by the European nitrogen cartel created to regulate destructive competition. By the end of the decade, domestic producers began to dominate the national market (Table 13.4). The wartime crisis of international trade had ultimately yielded strong networks in the national institutional quadrants. 
Such rapid growth in production could of course not have occurred without an equally dynamic demand for fertilisers. This was partly due to the establishment, by the early 1920s, of collective purchasing by agricultural co-operatives. Another factor was the drive for self-sufficiency during the First World War, which enabled production to exceed momentary demand, though with due consequences for prices. While by the early 1930s the fertiliser cartel had managed to stabilise prices, fertilisers had still become much cheaper: from 18 guilders per $100 \mathrm{~kg}$ in 1922 down to 5 in 1932. Demand was also stimulated by a knowledge infrastructure that transmitted new insights seamlessly to agricultural practice, and equally seamlessly fed farmers' experiences back into further R\&D. Goaded by the holy grail of increased productivity, the same knowledge infrastructure also promoted other innovations that multiplied the benefits of artificial fertilisers, like novel plant varieties and cultivation methods. (Chap. 13).

These developments led to higher agricultural productivity and thence to greater well-being: more income for farmers, and more domestically produced and affordable meat for the population at large (from $32 \mathrm{~kg} / \mathrm{capita} / \mathrm{year}$ around 1913 to no less than $63 \mathrm{~kg}$ in 1970). The radical differentiation of the supply chain and the massive expansion of production following on the demise of mixed farming grew out of the institutional arrangements just discussed. They were the seedbed for the institutional framework that nurtured post-1945 agricultural modernisation: the so-called Iron Triangle for policy making and the OVO knowledge infrastructure. This entailed a vast increase in knowledge and in the capital intensity of farming, again promoting further specialization: from mixed farming through animal husbandry and poultry farming towards either chickens for meat or chickens for eggs. Modernisation also increased the scale of production, but that process started earlier and deserves separate analysis.

\subsubsection{Expansion of Material Flows in the Grain-for-Meat Chain}

By 2010, the volume of meat production was 34 times that of 1850 while meat consumption per capita was 2.5 times as high. The stage for this increase was set between 1913 and 1970. By 1913, meat production had nearly quadrupled relative to 1850 though - due to exports and doubling of the population - per capita domestic consumption had increased by only $12.5 \%$. By 1970, however, meat production had again increased by a factor of 4.7. The bulk of this increase was due to post1945 modernisation policies. This increase was large enough to effect a per capita increase in meat consumption of 75\% (1913-1970) despite another doubling of the population and increased exports.

All in all, 1970 marked the end of a long struggle to provide sufficient meat; a struggle that had been a driving force in food production since 1850 . Food security had become political dogma around World War I, when socialist movements tried to 
seize power by exploiting societal unrest about food scarcity. The established parties countered by arranging emergency imports of food from England, leading to a lasting consensus on the need to increase domestic food production - an orientation that would inspire emergent corporatist arrangements for decades to come.

The most dramatic increase in food production occurred between 1945 and 1970 through a self-reinforcing process of modernisation, aimed at increasing GDP by producing affordable food domestically, while freeing agricultural labour for industry. This process became self-reinforcing due to its drivers: a persistent cultural inclination towards Americanisation (especially among young farmers) and the demonstrably increasing returns that encouraged imitation and provided investment capital. The 'logic' of investments in modernisation - increased capital intensity increased scale - increased scale - increased returns - new investments ${ }^{11}$ was equally inescapable. Modernisation was nurtured within an efficient knowledge infrastructure put together by post-war Minister Sikko Mansholt. From the early twentieth century co-operatives had provided capital for investments even to small farmers and the increased scale was facilitated by structural policies (land reclamation and improved water management) introduced by Mansholt shortly after WW II. All these elements were seamlessly connected through the iron triangle, a corporatist policy-making machinery shaped by Mansholt and rooted in the consensus that had emerged earlier and reinforced during the hardships of WW II.

Second, these years also witnessed the emergence of mass consumption, including food consumption. Not only did virtually the entire population now have access to essential foods, like meat, but also to a range of new foodstuffs - foreign food and items like chicken, convenience and luxury food - that had been unavailable till then. This was promoted by the landscape trends of increased traveling, decolonisation, the spread of refrigerators in households and retail stores and increased leisure time; as well as by the supermarket and the car. Institutionally, these factors were stimulated by governmental measures, especially subsidies for imported cooling and freezing equipment, the liberalisation of the retail sector, the liberalisation of wage increases, the issuing of the disk-of-five guidelines for a healthy diet and the introduction of a five-day working week. ${ }^{12}$

By 2010, with an $81 \mathrm{~kg} / \mathrm{capita} / \mathrm{year}$ meat consumption, the Dutch occupied a 44th place among 170 countries. While this is only slightly more than recommended by the World Health Organization, urban lifestyles are still nurturing an upward trend. This yields both health and ecological problems that have stimulated national policies and to which we will return in Chap. 24.

\footnotetext{
${ }^{11} \mathrm{~J}$. Grin, Changing governments, kitchens, supermarkets, firms and farms: the governance of transitions between societal practices and supply systems (2012), p. 35-56 in G. Spaargaren, P. Oosterveer, \& A. Loeber (Eds.), Food practices in transition: changing food consumption, retail and production in the age of reflexive modernity (New York), Routledge.

${ }^{12}$ Chapter 13; J. Grin, 'Changing governments, kitchens, supermarkets, firms and farms: the governance of transitions between societal practices and supply systems', in G. Spaargaren, P. Oosterveer, \& A. Loeber (Eds.), Food practices in transition: changing food consumption, retail and production in the age of reflexive modernity (Routledge 2012), 35-56.
} 


\subsection{Grain-for-Construction}

\subsubsection{Contemporary Problems and Historical Trends}

Between 1850 and 2010, flows of mineral assets steadily increased, absolutely by a factor of 32 , per capita by a factor of 16 . While the trend became visible between 1850 and 1910, it acquired momentum over the next 60 years, levelling off only after 1970 . Within the category of mineral assets, gravel is a revealing example: not only is it an important flow in its own right (constituting between 15-35\% of total mineral flows since 1910), but also growing by a factor of nearly 400 between 1850 and 2010. Most of this increase took place between 1910 and 1970, with the rise of (gravel-rich) concrete as construction material. As to spatiality: in recent years the share of imported gravel exceeded $80 \%$, twice the average for all mineral assets.

Gravel is a revealing example for understanding contemporary resource problems because its main environmental problem derives from its extraction: damage to the local landscape and ecosystems. The environmental effects of its actual use are less important. ${ }^{13}$ This implies that ecological damage is proportional to total gravel recovery. But the precise location where harm is being done ('here' or 'elsewhere') depends on how much is mined domestically vs. how much is imported. Between 1970 and 2010 the combined effect of reduced use and a higher share of import led to a fourfold decline in the amount of gravel extracted in the Netherlands, while the amount extracted 'elsewhere' (mainly the three neighbouring countries) has increased by $25 \% .{ }^{14}$

In terms of the two issues noted in research question Q1 (non-circularity of economic chains, and the sheer volume of mass flows), we note the following:

- mass flows of gravel increased by a factor of 24 between 1850 and 1910; while a nearly equal increase occurred over the following 60 years. After 1970, gravel use declined by just over $25 \%$.

- until around 1900, the gravel chain was largely circular: obsolete buildings, dikes and road infrastructure were demolished and reduced to re-usable materials.

- between 1850 and 1910, the share of imports quadrupled, reaching 67\% of the total or twice the mean percentage for mineral flows. Between 1910 and 1970, this share declined to $47 \%$, just 1.25 times the average, only to exceed $80 \%$ by 2010 in spite of an overall decrease in gravel use.

\footnotetext{
${ }^{13}$ The production of concrete and concrete products, an important use for gravel, contributes $1,1 \%$ and $1,7 \%$, respectively, to energy use and $\mathrm{CO} 2$ emissions; t0068e main problem is particulate matter emissions, constituting more than $10 \%$ of annual Dutch emissions.

M. Bijleveld, G.C. Bergsma, M. van Lieshout, Milieu-impact van betongebruik in de Nederlandse bouw Status quo en toetsing van verbeteropties (Delft, 2013), CE Delft. Publicatienummer: 13.2828.24

${ }^{14}$ F. Lambert, Massastromen in Nederland, 25, 35.
} 
To explain these features, we will discuss construction practices (of buildings, hydraulic engineering objects and road infrastructures), which were the main destinations for gravel, emphasising their institutional and spatial contexts.

\subsubsection{Volumes of Gravel: From Historically Vast Increases of Mass Flows to Gradual Decline}

In 1850, most of the 8800 ktons of material flows (58\%) comprised organic matter; subsoil mineral assets constituted a mere $28 \%$. Of those, clay, sand and gravel were the main bulk construction materials and largely extracted domestically; only gravel was imported to any degree (16\%, see Table 3.1). By 1910, both absolute gravel flows and the level of gravel imports had increased dramatically. Despite the enormous increase in imports, domestic extraction continued to increase over those six decades by a factor of 24 , from 50 to $1200 \mathrm{kton}$. In the next 60 years, it would increase again by a factor of 22, reaching more than 27,000 kton in 1970. This vastly growing demand for gravel derived both from an increase in construction efforts and from changes in the nature of construction.

\subsubsection{Increasing Construction Efforts}

Hydraulic engineering and transportation infrastructure, especially canals and railways, were the two sectors responsible for the initial increases in construction volumes. While the former was ordained by the geographic realities of living in a delta, infrastructure construction aimed to modernise an ailing economy. Around 1850, this was a critical issue both for the King and, after 1848, the national government, both of whom championed increasing welfare and thus supported modernisation and infrastructure construction.

Housing construction was another sector that required ever more building materials. In the final decades of the nineteenth century, growing societal concern about poor housing as a factor limiting popular well-being led to an enormous increase in urban housing construction. This was further stimulated by a number of long-term trends: population growth accelerated after 1880 as mortality fell in the wake of improvements in health care and nutrition. ${ }^{15}$ The upshot was a doubling of the population from 3.1 million in 1850 up to 5,9 million in 1910. In 1900, the housing shortage stood at $9 \%$ for the country as a whole (Graph 14.2), and even higher in the industrialising and rapidly growing cities. There, hygienists as well as a new caste

\footnotetext{
${ }^{15}$ Ekamper, P. R. van der Erf, N. van der Gaag, K. Henkens, E. van Imhoff, F. van Poppel, Bevolkingsatlas van Nederland - Demografische ontwikkelingen van 1850 tot heden. (2003), NIDI. Main results in English at https://www.nidi.knaw.nl/en/research/pd/120504
} 
of experts acquired a new audience as they voiced their concerns over the housing conditions of especially the lower class.

These groups promoted housing efforts according to the new hygienist norms. Their experiments helped shape the 1901 Housing Law. This law would become the cornerstone of a typically welfare-state institutional arrangement in housing and it immediately triggered a further acceleration in housing construction. As Graph 14.3 shows, annual housing production increased from around 15,000 in the late nineteenth century up to 20,000 around 1900 and more than 30,000 after 1905. As a consequence, the housing shortage fell to $3 \%$ by 1940 , only to rise again to nearly $20 \%$ after the destruction of the Second World War. Around 1970 it was back to 3\% again and fell to $2 \%$ by 2010 (Graph 14.2). Public surveys conducted between 1967 and 1972 revealed it to be perceived as the biggest social problem (cf. Chap. 15, note 41). Key drivers of the shortage were two long term trends: population growth (population again doubled between 1910 and 1970) and individualisation (leading to a demand for more rooms per household).

In consequence, housing production increased throughout most of the twentieth century. From next to nothing during World War I it rose to around 45,000 per annum during the interbellum, only to collapse again between 1940 and 1945. Between 1950 and the early 1970 s housing production tripled: from 50,000 to 150,000 per annum; in subsequent decades it would hover at around 100,000. These efforts were coordinated by the institutional arrangement that had emerged with the 1901 Housing Act. Government played a key role. It pushed for high production rates and was itself responsible for a significant share of the construction, aided and abetted by housing corporations and private parties (Graph 14.1). It also defined norms for the quality of dwellings (including the number of rooms and quality of construction) as well as for rent rates.

\subsubsection{Changing Construction Practice: Concrete and More Spacious Dwellings}

Two developments in housing design increased the demand for gravel in housing construction. The first was the use of concrete, especially after 1910. Concrete solved problem definitions prevailing since 1900: the need for cost-effective improvements in lower class living conditions, and the need to increase welfare through economic modernisation. Concrete also had symbolic appeal: it resonated with the cultural inclination toward progress.

The second development was an increase in the size of dwellings and in the number of rooms per dwelling, signs of increasing well-being and modernistic individualisation. The trend was driven by government policy and enabled by increasing national income. Between 1948 and the mid-1970s, the average floorplan increased from about 55 to around $70 \mathrm{~m}^{2}$ (Table 14.2) Also, while around 1900 only one-third of the homes had more than three rooms, this increased to more than two-thirds by 1930. By 1947 more than $75 \%$ of the homes had at least four rooms, and by 1970 more than $90 \%$. In that year, more than a third even had six rooms or more (Table 14.3). 


\subsubsection{More Concrete, More Gravel}

In light of these developments, concrete production grew apace. Concrete production took off in earnest during the 1920s, to climb to more than 11 million tons in 1970, still largely domestic in origin and consuming roughly $20 \%$ of the total gravel production. ${ }^{16}$ By the mid-1950s, largely due to demand from the housing sector, it had already climbed to $7 \mathrm{Mt}$, reaching $10 \mathrm{Mt}$ by 1960, $16 \mathrm{Mt}$ in 1965 and more than $20 \mathrm{Mt}$ in 1970, at which point output remained constant until 1980, when decline set in. ${ }^{17}$ By 2010, 28\% less gravel was being consumed than had been in 1970. While the decline in housing construction after the mid-1980s (from more than 100,000 units per year down to around 80,000) is clearly responsible, gravel consumption had already stabilised a decade earlier, due to the completion of the Delta Works and stagnation in the housing market (Chap. 19). ${ }^{18}$

\subsubsection{The End of Circularity and the Increasing Share of Import}

The evolution of the gravel-for-construction chain is typical of many Dutch chains (Chaps. 12 and 14): core demand practices (e.g. infrastructure and housing) become a central node in a network of specialised actors embedded in increasingly ramified supply chains. While gravel continues to flow directly and in its pristine form to the workplace, increasing quantities came to flow through separate chains, especially concrete, that also required coordination with other chains (sand and cement). These chains differ in terms of their circularity and the share of imported gravel. Both features were shaped by the tensions between demand, domestic gravel extraction and processing capacity and concerns about the local side- effects of extraction.

Why did the circularity of 1850 disappear? One key factor was the vast increase in demand. While around 1850 raw building materials were usually recovered in the course of demolishing obsolete constructions, this became untenable with the increased pace of construction of new infrastructures and the housing boom of the

\footnotetext{
${ }^{16}$ Rough estimates of gravel use in concrete production by JG, assuming that gravel constitutes roughly $50 \%$ of the mass of concrete - based on the traditional ' $1,2,3$ rule' for volumes and the roughly equal densities of cement, sand and gravel.

${ }^{17}$ CBS figures, cited by Ike (1985). While river gravel production had declined from 3 to about 0,65 Mton during the Second World War, it returned to pre-war levels within about a year, and then increased steadily up to 7,5 Mton over the next ten years. B.C.E. Janssen, 'Het veranderend gelaat van Nederland. Grindwinning in Midden-Limburg', Tijdschrift Nederlands Aardrijkskundig Genootschap, 1965, deel 82, 376-380.

Similarly, in Limburg, where much of the Dutch gravel extraction was concentrated, extraction increased immediately after WW II, stabilised around 1965 and declined again around 1975. Cf Provincie Limburg. Letter on 'Afronding Grindfonds' d.d. 4/10/2005. Janssen, 'Het veranderend gelaat', 378.

${ }^{18}$ Provincie Limburg. Letter on 'Afronding Grindfonds' d.d. 4/10/2005.
} 
twentieth century. Especially after the Second World War, with population growth, a housing shortage and a desire for more spacious homes driving the demand for construction, the volumes of material needed for new construction vastly exceeded what could be procured from the demolition of redundant facilities. Circularity had ceased to be a meaningful option.

What did remain throughout post-war reconstruction was strong governmental intervention in allocating scarce resources and ensuring a steady supply of subsoil mineral resources, especially gravel and marl as a basis for cement. In consequence, the national government took a firm stance when protests erupted in Limburg against the ENCI's proposed expansion of marl extraction near Maastricht. While the protest was unusual for the time, the outcome was more typical of the era: the ENCI got its concession for more cement production, although within strict spatial limits and subject to other mitigating measures.

Around 1950, a striving for national autarchy (after two wars and a crisis) intersecting with the perceived problem of insufficient housing made it necessary to expand domestic production of gravel (and sand). But extracting sand and gravel from beneath arable land ran afoul of efforts to solve another key problem of the time: insufficient food production. It also incited local protests against despoiling of the landscape. Gravel dredgers and the Province of Limburg eventually agreed on increased levels of extraction, but on condition of refilling the exhausted gravel pits and making them suitable for agriculture again - all paid for by a levy on the gravel. These kinds of compromises were institutionalised in 1965, with a Law on Subsoil Excavations coming into force by 1971. In the interval, nature and recreation became prominent issues. This brought alternative solutions for domestic gravel extraction to the fore, like turning empty gravel pits into economically viable recreational lakes. After 1970, local resistance finally got the upper hand. The national government capitulated by cutting back on domestic gravel extraction, banking on sources elsewhere within the EC. (Chaps. 16 and 19).

These vagaries of domestic gravel production and demand determined levels of import. Domestic gravel consumption increased 20-fold between 1910 and 1970. Nonetheless, the import share decreased from $67 \%$ to $47 \%$. And after the reorientation in 1970, in spite of a $28 \%$ decline in gravel consumption, imports again increased to $82 \%$ by 2010 .

We thus see how the volume of domestic gravel extraction, and with it levels of import, have responded to successive dominant problem definitions: increasing welfare, well-being and a striving for autarchy and the management of landscape quality. While it was the breakdown of circularity and increased gravel demand that incited more intensive domestic extraction and the despoiling of local landscapes, the increasing reliance on import implied that more and more of that damage was being exported elsewhere (see Sect. 23.4.1). 


\subsection{Plastics-for-Daily-Life}

\subsubsection{Exploring Contemporary Problems}

Plastics are an interesting example of the shift to processed products that occurred between 1910 and 1970 (Table 12.6). The shift originated with organic materials and mineral subsoil assets, but after 1945 the breakthrough of plastics brought fossil assets into the fold. The volume of plastics subsequently skyrocketed over the past half century: production in the Netherlands increased by more than a factor of 6 between 1970 and 2010; consumption by a factor 4 to $5 .^{19}$

While plastics have many industrial uses, households and consumer packaging are also an important market. Plastics were part and parcel of the new well-being achieved after 1960, when most people felt that their primary needs were satisfied. As discussed in Chaps. 14 and 16, plastics brought comfort, luxury and design products to the homes of all classes, as well as a new emphasis on convenience (packaging in retail and shopping practices!). While a contrapuntal critique persisted in seeing plastics as 'cheap' and 'artificial', the new products doubtless fostered more equality in the domain of 'second order well-being.' However, from a contemporary environmentalist point of view, plastics remain far from unproblematic, especially after their useful life. ${ }^{20}$

Plastics are seen as virtually synonymous with the 'waste society' - and for good reason. About half of the amount of plastic consumed by Dutch households is wasted - the same as for the EU as a whole. ${ }^{21}$ Also, the share of plastics in Dutch domestic waste flows increased threefold between 1970 and 2010. This is the outcome of a steady increase until 2005 followed by a policy-driven decline after $2008 .^{22}$ Symbolically and materially, plastic waste is exemplary for the inefficient husbanding of natural resources. Or, as the World Economic Forum ${ }^{23}$ puts it "Plastic packaging is an iconic linear application with USD 80-120 billion annual material value loss."

\footnotetext{
${ }^{19}$ F. Lambert, Massastromen in Nederland, 27, 37.

${ }^{20}$ Energy consumption is not the most crucial plastics problem. While plastics do belong to the most energy-intensive sectors, they account for only a few percent of Dutch $\mathrm{CO}_{2}$ emissions. Hoekstra en Van der Helm and Lintsen et al. argue that their production is less energy-intensive than that of the products substituted. In addition, plastic materials are relatively light, which makes some of its applications (e.g. in cars) less energy consuming. R. Hoekstra en R. van der Helm, Paper prepared for the 18th International Input-Output Conference (Sydney 2010), June 20-25th.

H. Lintsen, M. Hollestelle and R. Hölsgens (2017), The Plastics Revolution. How the Netherlands became a global player in plastics (Eindhoven 2017, open-access).

${ }^{21}$ Plastics Europe, Plastics - the Facts 2012. An analysis of European plastics production, demand and waste data for 2011. Plastics Europe (Brussels 2012), 9.

${ }^{22}$ It was $17 \%$ (increase by factor of 3,4 by 2010 ) and $14 \%$ (factor 2,8 ) for $2011-2015$, when the share was constant at $14 \%$. Rijkswaterstaat, Samenstelling huishoudelijk restafval. http://afvalmonitor.databank.nl/Jive/Jive?cat_open=landelijk\%20niveau/Samenstelling\%20van\%20huishoudelijk\%20restafval

${ }^{23}$ World Economic Forum, Ellen MacArthur Foundation and McKinsey \& Company, The New Plastics Economy - Rethinking the future of plastics (2016), retrieved from http://www.ellenmacarthurfoundation.org/publications
} 
Second, plastic waste that is not properly disposed of and processed may cause environmental harm ${ }^{24}$ Although there are increasing concerns about micro-plastics on land, little is known about them. More is known about damage to marine ecosystems, especially about entanglement and ingestion by fish. According to WEF et al., 2016, the oceans contain a mass of plastics amounting to 1/5 of the total mass of fish; they expect the quantities to be equal by 2050. Other known impacts concern changes in habitats and the transport of alien species, and human and animal health effects due to additives in plastics. While these problems also affect the Dutch marine environment, ${ }^{25}$ they are unevenly distributed over the globe, ${ }^{26}$ most notably affecting the Pacific.

In sum, contemporary problems with plastics are for here and now as well as for later and elsewhere; and they are a consequence of the vast waste flows produced. So it is relevant to understand the origin and increase of these waste flows. As above we explain the enormous growth of production and consumption, certainly fundamental to the increase of waste flows and we discuss the nature and evolution of the non-circularity of the chain.

\subsubsection{How the Chain Became So Vast: The Plastics Revolution}

The first plastics were developed at the end of the nineteenth century, and even in those early days their universal appeal was foreseen by, especially American, prophets of mass consumption. Until World War II, consumer products would constitute the most important market. By 1920, as the US started to export the new lifestyle, Berlin and Paris were becoming its European showcases ${ }^{27}$ - which may explain why Germany and France were early adopters of plastics - But wartime developments were at least as pertinent: novel systems, like plastics use in radar, or the use of plastics as substitutes for silk parachute textile after Japan entered the war (Chap. 15).

Prior to 1970 the Netherlands was certainly not a frontrunner in plastics consumption, joining the fray only after 1950. The same goes for production. In 1950, a mere 17 kton was produced, but that swiftly increased: to 239 kton by 1963 ,

\footnotetext{
${ }^{24}$ DG Environment of the EU (2011). Science for Environment Policy, In-depth Reports, Plastic Waste: Ecological and Human Health Impacts.

World Economic Forum, The New Plastics Economy.

${ }^{25}$ H.A. Leslie, M.D. van der Meulen, F.M. Kleissen, A.D. Vethaak, Microplastic litter in the Dutch marine environment: Providing facts and analysis for Dutch policymakers concerned with marine microplastic litter (Delft 2011).

${ }^{26}$ World Economic Forum, The New Plastics Economy.

${ }^{27} \mathrm{R}$. Oldenziel, A. de la Bruhèze, Theorizing the mediation junction for technology and consumption (2009) in A. de la Bruhèze and R. Oldenziel (eds) Manufacturing technology, manufacturing consumers: The making of Dutch consumer society, (Amsterdam: Aksant).
} 
900 kton by 1970,1785 kton by 1975 and up to nearly 9445 kton in $2010 .{ }^{28}$ Thus by 1963, the country was in the sub-top of producers (after the US, Germany and Japan) both in absolute and per capita terms, and by 1975 to the global top in terms of per capita production (106 kg/capita, compared to 78 and 45 for Germany and the US, respectively. ${ }^{29}$

That Dutch consumers were 'late adopters' is not that strange, given the country's culture of conservative domesticity that also retarded their adoption of mass consumption until well into the mid-twentieth century. ${ }^{30}$ But how then was it possible for the Netherlands to catch up so swiftly after the war? For one thing, the 1950s saw a 'silent revolution' in 'culture and mentality' ${ }^{31}$ (augmented by a cultural inclination towards 'Americanisation.' That shift, together with higher incomes, a five day working week, car mobility, TV and the emergence of the supermarket, created an avant garde in the Dutch middle class ready for the thrills of mass consumption ${ }^{32}$ (see also Chap. 22). These developments had been actively promoted by the Dutch government and by Marshall Plan projects, for example excursions by housewives and retailers to the US as well as exhibitions on the American way of life. ${ }^{33}$

Supply-side factors also help explain the swift growth of the chain. Frontrunners in industry and in the $R \& D$ sector shared the disposition to modernisation, Americanisation and mass consumption. That they were prepared to cater to the needs of the consumer market is evident from the nature of the plastic products: crockery, statues, medals, chains, dolls as well as furniture and clothing that incorporated the lower classes in the world of design and good taste. This coordination of supply and demand clearly helped the chain's swift expansion. And the underlying expectations about the future of mass consumption indeed stimulated firms to invest in further developments. (Chap. 15).

Yet, at a deeper level, earlier developments were responsible for the ability and preparedness of firms to join the plastics revolution. To be sure, Dutch firms had played no meaningful role in developing and producing plastics (excepting Philips' production of Bakelite). Three circumstances in particular enabled Dutch industry to catch up. Spatiality helped: DSM was located on top of the Limburg coal mines, and was very knowledgeable about fossil resources and ways to process them. Also, the globally important port of Rotterdam was a nodal point for the global oil trade,

\footnotetext{
${ }^{28}$ The number for 1950 is an estimate, inferred from Graph 3.1 in Lintsen et al., which shows that consumption and production were roughly equal. Numbers for 1963 and 1975 were taken from tables 3.2 and 3.3 in Lintsen et al.

${ }^{29}$ Numbers from table 3.1 in Lintsen et al., 2016.

${ }^{30}$ R. Oldenziel, M. Hård, Consumers, Tinkerers, Rebels: The People who Shaped Europe. (Series: Making Europe: technology and transformations, 1850-2000). (New York, 2012), Palgrave McMillan.

R. Oldenziel et al. Theorizing the mediation junction for technology and consumption.

${ }^{31}$ P. Luykx, P. Slot, Een stille revolutie? Cultuur en mentaliteit in de lange jaren vijftig. (Hilversum, 1997): Uitgeverij Verloren.

${ }^{32} \mathrm{~J}$. Grin, Changing governments, kitchens, supermarkets, firms and farms.

${ }^{33}$ R. Oldenziel, K. Zachman, Cold War Kitchen. Americanization, Technology, and European Users. (Cambridge, 2008, The MIT Press).
} 
making it an interesting plastics production site for multinational firms like Shell, DSM, Dow Chemical and ICI, that had developed much of the basic knowledge of polymer production. Other firms, like the AKU (predecessor of AkzoNobel), invested in delivering semi-finished products. Second, the Dutch government sponsored the establishment of a Plastics Institute within TNO - the national publicprivate R\&D agency. The Institute not only became a centre of expertise in plastics production and processing, but also played a main role in the development of material, product and process standards. Finally, other firms using plastics at small scales before the war - like the Draka cable factory, where plastics were used for insulation - were readily able to connect to this open network, promoting an efficient, economically viable sector. (Chap. 15).

The upshot was a self-organizing 'platform'-like institutional arrangement of polymer producers, processing firms and a supportive, public-private R\&D infrastructure. Its structure mimicked plastic production itself, which is essentially a matter of recombining and processing a limited set of basic polymers in virtually endless ways. The platform's links with transport nodes and the participation of major multinational firms facilitated the import of key materials and of products not (yet) domestically produced, as well as promoting export. The share of imports in plastics flows rapidly declined. In 1950 import and export were roughly equal to each other. By 1963, the import share was still 44\%, but by 1970 it had declined to $23 \%$. Over the same period, exports increased dramatically, ${ }^{34}$ further stimulating the sector: export shares were 52\% (1963), 70\% (1970) and 81\% (1975) and despite absolute increases in volume, they continue to fluctuate around the 1975 level, with e.g. $77 \%$ in 2010 and $83 \%$ in 2014 . One key factor behind the rapid expansion of both production and export after 1966 was the abundance of cheap domestic natural gas, a big competitive advantage in this energy intensive industry (Chap. 15).

Here, as in our other two cases, a traditional Dutch supply chain structure emerged as a complex web of specialized, differentiated suppliers and clients, wellembedded in trading activities and the associated institutional and spatial networks. By 2014 it included some 125 producers and more than 1300 intermediate processors. The mostly small and medium-sized enterprises comprising the sector were ranked first in innovation power among all SME sectors. The total turnover of the sector was 17.5 billion euro, i.e. about $2 \%$ of Dutch GDP.

The dark side of this significant contribution to economic welfare was increasing waste flows. Levels of waste production were more than proportional to domestic consumption. Less is destined for construction, and more for product categories with a shorter life cycle: applications in cars and electronics devices (two expressions of 'the new well-being' that evolved after 1960) and, most notably, an increasing use of plastics packaging, that inevitable handmaiden of modernisation. ${ }^{35}$ As a consequence, in 2014 no less than $40 \%$ of the plastics waste flow derived from short-lived applications.

\footnotetext{
${ }^{34}$ Percentages here and in the paragraphs below are taken from Lintsen et al. (2016, Graph 3.1 and tables 3.2, 3.3; for 1950, 1963 and 1975); and for 2014 from the Factsheet Rethinking Plastics issued by the Dutch Federation of Rubber and Plastics Industry NRK (Den Haag, 2016).

${ }^{35}$ Lintsen et all, The Plastics Revolution, 157-171.
} 


\subsubsection{Understanding the Chain's Non-circularity}

In contrast to the organic and mineral chains, the plastics chain has never been even close to circular. The most basic reasons are the same as those for the swift, positive reception of plastics: they are cheap; and they have a cultural resonance with 'progress' in the form of makeable materials.

Plastic packaging is emblematic. A cultural disposition towards disposability existed in Dutch society by the time plastics became an object of mass consumption. The Dutch were quite ready for "the the idea that packaging is made to be thrown away" (1957 industrial expert quote, cf. Chap. 15). A second- order cultural effect was that the modernistic ideal of the supermarket also promoted pre-packaged food products and beverages that dramatically increased the volume of plastic packaging, goaded of course by governmental food safety regulations. By the early 21 st century the idea had become deeply entrenched: plastics are "an iconic application of linearity", as the $\mathrm{WEF}^{35}$ put it.

These factors are clearly reflected in the figures. Between 1970 and 2010, the share of plastics in domestic waste increased from 5 to $17 \%$. Tellingly, in the same period the share of glass decreased from 11 to less than 5\%. By 2015, packaging constituted some two-thirds of the share of plastics in domestic waste (around 14\%). This consisted mostly of plastic bags and foil (3,5\%), shape fast packaging $(3 \%)$ and bottles (1,9\%, of which $1,2 \%$ for non-food products). ${ }^{36}$

The persistent non-circularity of the sector has other roots as well. As Lintsen et al. ${ }^{37}$ note, the production of basic polymers is based on an economy of scale, their processing into end products on a logic of scope (in terms of amounts and diversity of end products). These logics have become institutionally entrenched in the sector's platform-like institutional arrangement. This has led to a virtual neglect of the waste issue in the shaping of production practices and their connections to consumption practices. This is only aggravated by the fact of the Netherlands being a global plastics player, thus further uncoupling production from the conditions of use and waste practices.

\subsubsection{Energy Consumption}

Together, this lack of circularity and the vast expansion of the chain explains contemporary problems with plastics waste. As a twofold sector analysis by Hoekstra et al. ${ }^{38}$ demonstrates, increased volume is also one key factor explaining increases

\footnotetext{
${ }^{36}$ Rijkswaterstaat Samenstelling van het huishoudelijk restafval, sorteeranalyses 2015; Gemiddelde driejaarlijkse samenstelling 2014. (Utrecht2016), Rijkswaterstaat.

${ }^{37}$ H. Lintsen, M. Hollestelle and R. Hölsgens (2017), The Plastics Revolution. How the Netherlands became a global player in plastics Eindhoven 2017, open-access).

${ }^{38}$ All figures in this and the preceding paragraph are from R. Hoekstra en R. van der Helm, Paper prepared for the 18th International Input-Output Conference (Sydney 2010), June 20-25th
} 
in the energy intensity of Dutch industry in the years 1961-1974. The abundance of natural gas since the mid-1990s increased the share of energy intensive sectors like the chemical industry, lured by golden opportunities in export markets.

The sector's sensitivity to energy costs made it especially responsive to the 1973 and 1979 oil crises. Reducing energy consumption became a guiding principle for innovation in chemical processing in general: new machinery, electronic process control and design and, more recently, 3D printing. ${ }^{47}$ In consequence, the sector's overall energy intensity declined by $7.5 \%$ between 1961 and 2008; its growth rate for $\mathrm{CO}_{2}$ emissions dropped from $11.4 \%$ per year (1961-1974) to zero (1975-1989), and between 1990 and 2008 emissions even dropped at a rate of 3\% per year. Its share in national energy consumption became $11.6 \%$, and in $\mathrm{CO}_{2}$ emissions $7.2 \%$.

Yet with an eye to the future it is important to note that the reduction in the sector's energy intensity was only half that of the Dutch economy as a whole (15\%). Also, after 1990, the reduction in energy intensity was more than offset by an expansion of production, mainly driven by export markets. The changed fuel mix incorporating more natural gas was both behind relatively low emissions, and behind the increasing volume, especially through the export effect. In sum, for the decades to come, the fuel mix will be a key determinant of $\mathrm{CO}_{2}$ emissions and exports alike.

\subsection{Electricity for Households}

\subsubsection{Exploring the Problem}

Several sectors were chiefly responsible for making the Dutch economy much more energy-intensive: air and water transportation, the chemical industry and agriculture, but certainly also the utilities. In fact, the latter accounted for one third of the total increase in $\mathrm{CO}_{2}$ emissions between 1960 and 2008. In this sector the main driver of changes in energy flows was not export, but household consumption - in spite of the fact that the latter accounted for a mere $20 \%$ of all electricity consumption. Exports (by other Dutch industries!) take second place as drivers of change. ${ }^{39}$ We focus here on household consumption, on practices that consume electricity and that reflect the evolution of well-being.

The sector is relevant not only for explaining key contemporary dynamics; it is also significant in absolute terms. In 2008 the sector was the single biggest consumer of energy (11,8\% of total) and the single biggest producer of $\mathrm{CO}_{2}$ emissions $(29,4 \%)$. The sector is thus a major culprit in resource depletion and climate problems 'later' and 'elsewhere.'

Against this background, we will seek to understand

- the development of the dynamic relationships between household electricity consumption and overall electricity production;

\footnotetext{
${ }^{39}$ All figures in this and the next paragraph are from R. Hoekstra en R. van der Helm (2010).
} 
- the evolution of domestic electricity demand

- the development of the relationships between electricity production, overall primary energy use and $\mathrm{CO}_{2}$ emissions.

\subsubsection{Households and Electricity Production}

As in most countries, electricity in the Netherlands was initially a lighting technology, first adopted by businesses and well-to-do households, as a replacement for dangerous, smelly and noisy gas lighting. Around 1900, when electricity also became a source of motive power for trams and factories, municipalities and provinces began to establish electrical power plants (Chap. 16).

As the networks spread geographically to include additional users, marginal costs for additional connections declined: a well-known mechanism of network expansion. (Chap. 14) The resulting dynamic networks linked centralised production to decentralised consumption. That structure implied an economic incentive to further electrify households. One early example, the vacuum cleaner, was successful partly because it took over a rather laborious domestic task. Like other appliances (the electrical iron being an important second example), its use was promoted by 'trailblazers of the consumer society,' intermediaries with close ties to the product developers (Chap. 16). These intermediaries not only fostered receptivity for electrical novelties among housewives, but also transmitted housewives' experiences and needs back to R\&D departments. ${ }^{40}$

These intermediaries were certainly driven by the economic logic of (municipal) electricity companies, but also drew on the efforts of feminists. Drawing on an international cultural ('landscape') inclination towards a modern rational lifestyle as well as on an indigenous preference for a healthy, cozy family life, contemporary feminists encouraged middle-class women to reconsider their overstuffed homes and adopt more efficient approaches to housework. The aim was also to create more free time for social engagement, especially for working-class women. In 1912, the Netherlands Association of Housewives was founded; followed in 1932 by the Women's Electricity Society. These women, informed by experience and inspired by scientific advances, undertook a variety of initiatives to rationalise the household: 'home supervisors', experimental cooking schools, conferences and exhibitions, and publications on how to manage a household in more rational and hygienic ways. ${ }^{41}$

\footnotetext{
${ }^{40} \mathrm{~T}$. de Rijk, Het elektrische huis: vormgeving en acceptatie van elektrische huishoudelijke apparaten in Nederland. (Rotterdam, 1998). P. van Overbeeke \& G.P.J. Verbong, 'De strijd om het huishouden' in: J.W. Schot en anderen (red.), Techniek in Nederland in de twintigste eeuw. (Zutphen 2000), 174-189.

${ }^{41}$ R. Oldenziel \& Carolien Bouw (ed.). Schoon genoeg. Huisvrouwen en huishoudtechnologie, 1898-1998. (Nijmegen 1998). A.H. van Otterloo, 'Voeding', in J.W. Schot en anderen (eds.) Techniek in Nederland in de twintigste eeuw (Zutphen 2000), 140-150. L. Bervoets and R. Oldenziel (2009). 'Speaking for Consumers, Standing Up as Citizens: the Politics of Dutch Women's organizations and the Shaping of Technology, 1880-1980', in: Adri Albert de la Bruhèze
} 
Against this background, it is easy to see why electrification could proceed so swiftly. In Amsterdam, for instance, some 7000 homes were connected in 1913. By the end of the First World War, that number exceeded 100.000. By 1924, some 144.000 out of a total population of 165.000 were connected. ${ }^{42}$ Sockets had become standard in new homes, as "the most effective propagators of electrification" inasmuch as they "yelled for contact." The assumption that electricity was just there, ready to hand, became deeply entrenched, helping to pave the way for a swift electrification of the household.

This central-decentral, fossil fuel-based infrastructure, as well as the cultural esteem for the 'electric home', ${ }^{43}$ as both an expression of well-being and a symbol of faith in progress, still shape present-day electricity consumption and production. That said, privatisation of electricity production and distribution has begun to corrode electrical centralism. Also while user demand initially sprung from a desire to rationalise the household, and thus improve quality of life (Chap. 22), around 1960 the emphasis shifted towards luxury, convenience and mass consumption (see also Graph 17.1). Since the mid-1990s, ICT appliances have added another layer to this trend and produced a space for the electronic homo ludens.

\subsubsection{The Evolution of Domestic Electricity Demand}

The increase in consumptive expenditures has led to a drastic increase in domestic energy consumption, from 3,2 to $12,5 \mathrm{GJ} /$ capita between 1950 and 2010. But not uniformly. Between 1982 and 1988 it decreased by $12 \%$ to remain at that level until 1993; it then increased until 2005, only to decrease again: by 2010 it was back at the 2000 level.

To understand this pattern we need more details. In 1988, an average household used $20 \%$ of its electricity for cooling, in 1993 this had fallen to $17 \%$; in the same period lighting declined from about $25 \%$ to about $17 \%$ and the share of audio/video appliances increased from 8.5 to $12 \% .{ }^{44}$ ICT applications accounted for nearly the entire $20 \%$ growth of overall electricity consumption between 1990 and 2006. By 2008 , computers, communication and auxiliary appliances accounted for $15 \%$ of the average household's electricity consumption. ${ }^{45}$

and Ruth Oldenziel (eds.), Manufacturing Technology, manufacturing consumers. The making of Dutch consumer society. Amsterdam: Aksant, p. 44-47.

${ }^{42} \mathrm{P}$. van Overbeeke, Kachels, geisers en fornuizen. Keuzeprocessen en energieverbruik in Nederlandse huishoudens, 1920-1975 (Hilversum 2001: Verloren), 46.

${ }^{43}$ T. de Rijk, Het elektrische huis.

${ }^{44}$ K.F.B. de Paauw, J.M. Bais, Sectorstudie huishoudens en woningen. (Petten, 1995: E).

${ }^{45}$ Clevers, P. Popma, Energiemonitor ICT 2008. (Den Haag, 2009), Tebodin/Ministerie van Economische Zaken.

J. Ganzevles, R. van Est, Energie 2030. Maatschappelijke keuzes van nu. (Den Haag: Rathenau Instituut). 
This evolution of domestic energy consumption is the outcome of heterogeneous developments. On the one hand, consumption increased due to the proliferation of different types of appliances and their penetration into households (e.g. dishwashers; audio/video; ICT), and more frequent use (e.g. washing machine). On the other hand, many appliances have become more energy efficient. ${ }^{46}$ The development of more efficient light bulbs explains the decrease in the share of lighting: from 710 down to $511 \mathrm{kwh} / \mathrm{yr}$./household between 1988 and 1993, and further down to $390 \mathrm{kWh}$ in $2014 .{ }^{47}$ For cooling, increased refrigerator efficiency was compensated by increases in volume and the rapid adoption of the freezer: total electricity consumption for cooling was $578 \mathrm{kWh}$ in 1988, and 555 in 1993. Due to the increased number and variety of audio and video appliances, their power consumption increased from 247 to $391 \mathrm{kWh}$ between 1988 and 1993, after which more efficient appliances began to turn the tide - down to $191 \mathrm{kWh}$ by $2014 .{ }^{48}$ In a similar pattern, the more recent ICT appliances first increased domestic consumption but with e.g. the introduction of laptops their consumption declined again.

\subsubsection{The Evolution of Energy and the $\mathrm{CO}_{2}$ Intensity of Electricity Production}

The Dutch electricity market is again traditional in the sense of being a trade market: the volume of trade in electrictiy is twice what is demanded by Dutch industries and households. ${ }^{49}$ That said, we can still say something about the energy and $\mathrm{CO}_{2}$ intensity of electricity production. While in 1922, some $22 \mathrm{MJ}$ of primary energy was needed to generate one kWh of electricity; by the 1940s, only 15 MJ was needed. Upon the introduction of natural gas (Chap. 15) and with improved efficiency, consumption per kWh rapidly declined to $10 \mathrm{MJ}$ by 1964 . By 2000 , due to improvements in efficiency, it had further declined to around $8.4 \mathrm{MJ} / \mathrm{kWh}$ until 2003 , and again from 8.1 in 2004 to 7.0 in 2011. But in 2012, the energy intensity again increased, up to $7.4 \mathrm{MJ} / \mathrm{kWh}$ by 2015 , due to the replacement of gas by coal in power plants. Not surprisingly, $\mathrm{CO}_{2}$ consumption per kWh declined by $20 \%$ between 2000 and 2011, but then increased again by $20 \%$ due to this change in the fuel mix. In

\footnotetext{
${ }^{46} \mathrm{H}$. Jeeninga, Analyse energieverbruik sector huishoudens, 1982-1996. Achtergronddocument bij het rapport. 'Monitoring energieverbruik en beleid Nederland. (Petten, 1997: ECN).

$\mathrm{CPB}$, Naar een efficiënter milieubeleid; een maatschappelijk-economische analyse van vier hardnekkige milieuproblemen. (Den Haag, 2000): CPB/SDU.

${ }^{47}$ K.F.B. de Paauw, J.M. Bais, Sectorstudie huishoudens en woningen, 22.

${ }^{48}$ K.F.B. de Paauw, J.M. Bais, Sectorstudie huishoudens en woningen, 22. ECN, Energie-Nederland en Netbeheer Nederlan, Energietrends, 2014 Rapport ECN-O--14-041 (z.pl 2014).

${ }^{49}$ ECN, Energie-Nederland en Netbeheer Nederland, Energietrends, 2016 Rapport ECN-O--16031 (z.pl 2016).
} 
short, energy intensity in electricity production, just like that in plastics production, responded to changes in fuel mix related to the availability (and exhaustion) of domestic natural gas between about 1960 and 2013.

\subsection{In Conclusion}

In this chapter, we have discussed how currently problematic couplings between GDP growth, well-being, resource / energy use and pollution have historically emerged. Drawing upon the rich historical discussions in previous chapters, and guided by transition theory, we have shown how this may be understood on basis of the evolution of practices of production, consumption, and distribution, as well as their guiding problem definitions and value orientations and their structural and spatial embedment of these practices. We showed for three discuss supply chains (grain-for-meat; gravel-for-construction; and plastics-for-domestic-quality of life) how they became non-circular in character, and how material flows in these chains expanded so vastly, especially since 1960 .

We will now turn our analytical perspective 180 degrees. Looking from the perspective of a more sustainable society, now widely desired, we will discuss strategies to make the first three value chains less massive and more circular, and to reduce the climate change effects of the fourth one, preferably down to zero. While we will, in the next chapter, contextualize this discussion also in ongoing long term trends that will shape early twenty-first century developments, we will draw on the analysis of this chapter to appreciate how historically evolved practices, structures, and spatial conditions both constrain and enable such strategies.

\section{Literature}

Beck, Ulrich, (1997): The re-invention of politics. Rethinking Modernity in the Global Social Order (Cambridge: Polity Press).

Bervoets, L. and R. Oldenziel (2009). 'Speaking for Consumers, Standing Up as Citizens: the Politics of Dutch Women's organizations and the Shaping of Technology, 1880-1980,' in: Adri Albert de la Bruhèze and Ruth Oldenziel (eds.), Manufacturing Technology, manufacturing consumers. The making of Dutch consumer society. Amsterdam: Aksant, p. 41-72.

Bijleveld, M.M. (Marijn), G.C. (Geert) Bergsma, M. (Marit) van Lieshout (2013). Milieu-impact van betongebruik in de Nederlandse bouw Status quo en toetsing van verbeteropties. Delft, CE Delft. Publicatienummer: 13.2828.24

Brauch, Hans Günter, Úrsula Oswald Spring, John Grin, Czeslaw Mesjasz, Patricia Kameri-Mbote, Navnita Chadha Behera, Béchir Chourou, Heinz Krummenacher (Eds., 2009): Facing Global Environmental Change: Environmental, Human, Energy, Food, Health and Water Security Concepts. Hexagon Series on Human and Environmental Security and Peace, vol. 4 (Berlin Heidelberg - New York: Springer-Verlag).

Brauch, Hans Günter, Úrsula Oswald Spring, Czeslaw Mesjasz, John Grin, Patricia Kameri-Mbote, Béchir Chourou, Pal Dunay, Jörn Birkmann (Eds., 2011): Coping with Global Environmental 
Change, Disasters and Security - Threats, Challenges, Vulnerabilities and Risks. Hexagon Series on Human and Environmental Security and Peace, vol. 5 (Berlin - Heidelberg New York : Springer-Verlag).

CBS (2015). Electriciteit in Nederland.

Clevers, \& P. Popma (2009). Energiemonitor ICT 2008. Den Haag: Tebodin/Ministerie van Economische Zaken.

Cordell, Dana (2010). The Story of Phosphorus:Sustainability implications of global phosphorus scarcity for food security. Linköping: Linköping University Press.

$\mathrm{CPB}$, Naar een efficiënter milieubeleid; een maatschappelijk-economische analyse van vier hardnekkige milieuproblemen. (Den Haag, 2000): CPB/SDU.

Denkgroep Duurzame Veehouderij (2001). Toekomst voor de veehouderij. Agenda voor een herontwerp voor de sector. Advice to the Dutch Agricultural Minister.

de Paauw, K.F.B. \& J.M. Bais (1995). Sectorstudie huishoudens en woningen. Petten: ECN

Ekamper, P. R. van der Erf, N. van der Gaag, K. Henkens, E. van Imhoff \& F. van Poppel (2003), Bevolkingsatlas van Nederland - Demografische ontwikkelingen van 1850 tot heden. NIDI. Main results in English at https://www.nidi.knaw.nl/en/research/pd/120504

DG Environment of the EU (2011). Science for Environment Policy $\mid$ In-depth Reports $\mid$ Plastic Waste: Ecological and Human Health Impacts.

ECN, Energie-Nederland en Netbeheer Nederland, Energietrends, 2014 Rapport ECN-O--14-041 (z.pl 2014).d

ECN, Energie-Nederland en Netbeheer Nederland, Energietrends, 2016 Rapport ECN-O--16-031 (z.pl 2016)

J. Ganzevles, R. van Est Energie 2030. Maatschappelijke keuzes van nu. (Den Haag: Rathenau Instituut)

Grin, John, Henk van de Graaf \& Philip Vergragt (2003). 'Een derde generatie milieubeleid: Een sociologisch perspectief en een beleidswetenschappelijk programma,' Beleidswetenschap, jrg. 17, nr. 1, p. 51-72.

Grin, John, 2010: "Understanding Transitions from a Governance Perspective", Part III,) in: Grin, John; Rotmans, Jan; Schot, Johan, 2010: Transitions to Sustainable Development. New Directions in the Study of Long Term Structural Change (New York: Routledge): 223-314.

Grin, J. (2012). Changing governments, kitchens, supermarkets, firms and farms: the governance of transitions between societal practices and supply systems, p. 35-56 in G. Spaargaren, P. Oosterveer, \& A. Loeber (Eds.), Food practices in transition: changing food consumption, retail and production in the age of reflexive modernity. New York [etc.]: Routledge.

Grin, John, Niki Frantzeskaki, Vanessa Castan Broto and Lars Coenen (2017) 'Sustainability Transitions and the City: Linking to transition studies and looking forward " chapter 22 (conclusions) in: Niki Frantzeskaki; Vanessa Castan---Broto; Lars Coenen (ed.s), Urban Sustainability Transitions.

Harmelink, M., L. Bosselaar, J. Gerdes, P. Boonekamp, R. Segers, H. Pouwelse, M. Verdonk (2012). Berekening van de CO2-emissies, het primair fossiel energiegebruik en het rendement van elektriciteit in Nederland. Agentschap NL/CBS/ECN/PBL.

Heckenmüller, Markus Daiju Narita, Gernot Klepper (2014). Global Availability of Phosphorus and Its Implications for Global Food Supply: An Economic Overview. Kiel Working Paper No. 1897. University of Kiel.

Hees, E. (2013). Voedsel, grondstoffen en geopolitiek. Rapportage aan het Platform Landbouw, lnnovatie \& Samenleving. Culemborg: CLM. P. 23-28

Hoekstra, R. en R. van der Helm (2010). Paper prepared for the 18th International Input-Output Conference. Sydney: June 20-25th.

Hesselmans, A., 1993. 'Elektriciteit', in: H.W. Lintsen en anderen (red.), Geschiedenis van de techniek in Nederland (Zutphen: Walburg Pers, deel III, 135-161.

Hodson, Mike; Marvin, Simon, 2010: "Can cities shape socio-technical transitions and how would we know if they were?", in: Research Policy, 39: 477-485. 
Ike, P (1985) Grind gegvalueerd: nadere beschouwing van de tot op heden opgestelde prognoses en aanbevelingen voor nieuw op te stellen prognoses. Delft : Delftse Universitaire Pers.

B.C.E. Janssen, B.C.E. (1965). 'Het veranderend gelaat van Nederland. Grindwinning in MiddenLimburg' in: Tijdschrift Nederlands Aardrijkskundig Genootschap, deel 82, p. 376-380.

Jeeninga, H. (1997). Analyse energieverbruik sector huishoudens, 1982-1996. Achtergronddocument bij het rapport. 'Monitoring energieverbruik en beleid Nederland'. Petten: ECN. m

Jetten, L., B. Merkx, J. Krebbekx en G. Duivenvoorde (2011). Onderzoek kunststof afdankstromen in Nederland, Berenschot/Agentschap NL/DPI Value Centre/Federatie NRK.

Leslie, H.A., M.D. van der Meulen, F.M. Kleissen, A.D. Vethaak (2011). Microplastic litter in the Dutch marine environment: Providing facts and analysis for Dutch policymakers concerned with marine microplastic litter. Delft: Deltares

Lintsen, H., M. Hollestelle and R. Hölsgens (2017), The Plastics Revolution. How the Netherlands became a global player in plastics Eindhoven: Foundation for the History of Technology (open-access)

Luykx, Paul en Pim Slot, (ed., 1997). Een stille revolutie? Cultuur en mentaliteit in de lange jaren vijftig. Hilversum: Uitgeverij Verloren.

Mom, G.P.A. \& R. Filarski (2008). Van transport naar mobiliteit: De mobiliteitsexplosie (18952005). Zutphen: Walburg.

Oldenziel, R. and Karin Zachman (eds.; 2008). Cold War Kitchen. Americanization, Technology, and European Users. Cambridge, MA: The MIT Press.

Oldenziel, R. and Albert de la Bruhèze, A. (2009) 'Theorizing the mediation junction for technology and consumption', in A. Albert de la Bruhèze and R. Oldenziel (eds) Manufacturing technology, manufacturing consumers: The making of Dutch consumer society, Amsterdam: Aksant.

Oldenziel, Ruth \& Carolien Bouw (ed., 1998). Schoon genoeg. Huisvrouwen en huishoudtechnologie, 1898-1998. Nijmegen: SUN.

Oldenziel, R. \& Hård, M. (2012). Consumers, Tinkerers, Rebels: The People who Shaped Europe. (Series: Making Europe: technology and transformations, 1850-2000). New York: Palgrave McMillan.

Otterloo, A. H. van (2000). 'Voeding', in J.W. Schot en anderen (eds.) Techniek in Nederland in de twintigste eeuw. Zutphen: Walburg Pers, Deel III, 235-374.

Ours, J.C. van (1985) Gezinsconsumptie in Nederland 1951-1980. Rotterdam: 010 Uitgeverij.

Overbeeke, P. van, G.P.J. Verbong (2000). 'De strijd om het huishouden' in: J.W. Schot en anderen (red.), Techniek in Nederland in de twintigste eeuw. Zutphen : Walburg Pers, deel II, 174-189.

Overbeeke, P. van (2001). Kachels, geisers en fornuizen. Keuzeprocessen en energieverbruik in Nederlandse huishoudens, 1920-1975. Hilversum: Verloren.

Plastics Europe (2012), Plastics - the Facts 2012. An analysis of European plastics production, demand and waste data for 2011. Plastics Europe. Brussels: Plastics Europe

Raven, Rob; Schot, Johan; Berkhout, Frans, 2012: "Space and scale in socio-technical transitions", in: Environmental Innovation and Societal Transitions, 4: 63-78.

Ridder, M. de, S. de Jong, J. Polchar and S. Lingemann Risks and Opportunities in the Global Phosphate Rock Market. The Haguye: The Hague Centre for Strategic Studies (HCSS). Rapport No $17 \mid 12$ | 12 .

Rijk, T. de (1998). Het elektrische huis: vormgeving en acceptatie van elektrische huishoudelijke apparaten in Nederland. Rotterdam: Uitgeverij 010.

Rijkswaterstaat (2016). Samenstelling van het huishoudelijk restafval, sorteeranalyses 2015; Gemiddelde driejaarlijkse samenstelling 2014. Utrecht : Rijkswaterstaat.

Segers, R. (2014). Rendementen en $\mathrm{CO}_{2}$-emissie van elektriciteitsproductie in Nederland, update 2012. Den Haag: CBS.

Smith, Adrian; Voß, Jan-Peter; Grin, John, 2010: "Innovation studies and sustainability transitions: the allure of adopting a broad perspective, and its challenges", in: Research Policy, 39: 435-448. 
Späth, Philipp; Rohracher, Harald, 2010: “'Energy regions': The transformative power of regional discourses on socio-technical futures, in: Research Policy, 39, 4: 449-458.

Späth, Philipp; Rohracher, Harald, 2014: "Beyond Localism: The Spatial Scale and Scaling in Energy Transitions". in: Padt,

Frans J. G.; Opdam, Paul F. M.; Polman, Nico B. P.; Termeer, Kathrien J. A. M. (Eds.): Scalesensitive Governance of the Environment (Oxford: John Wiley): 106-121.

Switzer, Andrew; Bertolini, Luca; Grin, John, 2013: "Transitions of Mobility Systems in Urban Regions: A Heuristic Framework", in: J. Environmental Policy and Planning, 15, 2: 141-160.

Switzer, Andrew, Luca Bertolini \& John Grin (2015). 'Understanding transitions in the regional transport and land-use system: Munich 1945 - 2013', Town Planning Review, vol. 86 no. 6. p. 699-723.

Truffer, Bernhard, Coenen, Lars, 2012: "Environmental Innovation and Sustainability Transitions in Regional Studies", in: Regional Studies, 46, 1: 1-21.

van der Bie, R.J. \& J.P. Smits (2001). Tweehonderd jaar. statistiek in tijdreeksen. 1800-1999. Den Haag/Groningen: CBS/ RU Groningen.

World Economic Forum, Ellen MacArthur Foundation and McKinsey \& Company, (2016). The New Plastics Economy - Rethinking the future of plastics (http://www.ellenmacarthurfoundation.org/publications).

Wetenschappelijke Raad voor het Regeringsbeleid (WRR) (2014). Naar een voedselbeleid (rapport nr. 93). Den Haag/Amsterdam: WRR/Amsterdam University Press.

Zeijts, H. van, M.M. van Eerdt, W.J. Willems, G.A. Rood, A.C. den Boer, D.S. Nijdam (2010). Op weg naar een duurzame veehouderij. Ontwikkelingen tussen 2000 en 2010. Den Haag/ Bilthoven : Planbureau voor de Leefomgeving (PBL).

Open Access This chapter is licensed under the terms of the Creative Commons Attribution 4.0 International License (http://creativecommons.org/licenses/by/4.0/), which permits use, sharing, adaptation, distribution and reproduction in any medium or format, as long as you give appropriate credit to the original author(s) and the source, provide a link to the Creative Commons license and indicate if changes were made.

The images or other third party material in this chapter are included in the chapter's Creative Commons license, unless indicated otherwise in a credit line to the material. If material is not included in the chapter's Creative Commons license and your intended use is not permitted by statutory regulation or exceeds the permitted use, you will need to obtain permission directly from the copyright holder.

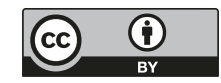

